\title{
Hubungan Karakteristik Individu dengan Pengetahuan tentang Pencegahan Coronavirus Disease 2019 pada Masyarakat di Kalimantan Selatan
}

\author{
Anggun Wulandari ${ }^{1 凶}$, Fauzie Rahman $^{1}$, Nita Pujianti ${ }^{1}$, Ayu Riana Sari ${ }^{1}$, \\ Nur Laily ${ }^{1}$, Lia Anggraini ${ }^{1}$, Farid Ilham Muddin ${ }^{1}$, Agus Muhammad Ridwan ${ }^{1}$, \\ Vina Yulia Anhar ${ }^{1}$, Muhammad Azmiyannoor ${ }^{1}$, Diki Bima Prasetio ${ }^{2}$ \\ ${ }^{1}$ Program Studi Kesehatan Masyarakat, Fakultas Kedokteran, Universitas Lambung Mangkurat Banjarbaru \\ ${ }^{2}$ Fakultas Kesehatan Masyarakat, Universitas Muhammadiyah Semarang
}

\section{Info Artikel}

Diterima 1 Mei 2020

Disetujui 3 Mei 2020

Diterbitkan 28 Mei 2020

\section{Kata Kunci:}

Karakteristik Individu

Pengetahuan

Covid-19

e-ISSN:

2613-9219

Akreditasi Nasional:

Sinta 4

Keywords:

Individual Characteristics

Knowledge

Covid-19

${ }^{凶}$ Coresponding author:
anggunwd2078@gmail.com

\begin{abstract}
Abstrak Latar Belakang: Coronavirus Disease 2019 (Covid-19) saat ini menjadi permasalahan dunia yang serius dengan jumlah kasusnya yang selalu mengalami peningkatan setiap harinya. Tujuan: Untuk mengetahui pengetahuan masyarakat Kalimantan Selatan tentang pencegahan Covid-19 beserta faktor karakteristik individu. Metode: Desain cross sectional dengan sampel berjumlah 1190 orang yang dipilih dengan menggunakan purposive sampling. Instrumen penelitian menggunakan kuesioner google form. Hasil: Dari 1190 masyarakat yang menjadi responden merupakan masyarakat dengan kategori umur remaja yaitu sebesar 93,7\%, status pekerjaan tidak bekerja sebesar $77,2 \%$, berjenis kelamin perempuan sebesar $66,3 \%$, posisi dalam keluarga sebagai anggota rumah tangga yaitu sebesar $97,8 \%$, dan mempunyai pengetahuan yang baik tentang pencegahan Covid-19 sebesar 69,2\%. Hasil uji chi square menunjukan nilai $p$ antara umur, jenis kelamin, pendidikan, status pekerjaan dan posisi dalam keluarga dengan pengetahuan tentang pencegahan Covid19 adalah 0,386, 0,013, 0,428, 0,515, dan 0,999. Kesimpulan: Umur, pendidikan, status pekerjaan dan posisi dalam keluarga dengan tidak memiliki hubungan dengan pengetahuan tentang pencegahan Covid-19. Namun, jenis kelamin memiliki hubungan dengan pengetahuan tentang pencegahan Covid-19.
\end{abstract}

\begin{abstract}
Background: Coronavirus (Covid-19) is serious world problem with the number of cases that is always increasing every day. Objective: To know the knowledge of the people in South Kalimantan about the prevention of Covid-19 along with individual characteristic factors. Method: Cross sectional design with a sample taken 1190 people selected using purposive sampling. The research instrument uses the google questionnaire form. Result: Of the 1190 respondents who were respondents were those in the adolescent age category of $93.7 \%$, unemployed employment status of $77.2 \%$, female sex of $66.3 \%$, position in the family as a household member at $97.8 \%$, and have a good knowledge of Covid-19 prevention at $69.2 \%$. Chi square test results showed the p-value between age, sex, education, work status and position in the family with knowledge about Covid-19 prevention were 0.386, 0.013, 0.428, 0.515, and 0.999. Conclution: We found no significant correlation between age, education, employment status and position in family with knowledge about Covid-19 prevention. However, gender has a significant correlation with knowledge about Covid-19 prevention.
\end{abstract}

(C) 2020 Program Studi S-1 Kesehatan Masyarakat Universitas Muhammadiyah Semarang 


\section{Pendahuluan}

Coronavirus adalah keluarga besar virus yang menyebabkan penyakit mulai dari gejala ringan sampai berat. Ada setidaknya dua jenis coronavirus yang diketahui menyebabkan penyakit yang dapat menimbulkan gejala berat seperti Middle East Respiratory Syndrome (MERS) dan Severe Acute Respiratory Syndrome (SARS). Coronavirus Disease 2019 (Covid-19) adalah penyakit jenis baru yang belum pernah diidentifikasi sebelumnya pada manusia. Virus penyebab Covid-19 ini dinamakan Sars-CoV-2. Virus corona adalah zoonosis (ditularkan antara hewan dan manusia). Penelitian menyebutkan bahwa SARS ditransmisikan dari kucing luwak (civet cats) ke manusia dan MERS dari unta ke manusia. Adapun hewan yang menjadi sumber penularan Covid-19 ini masih belum diketahui [1].

Tanda dan gejala umum infeksi Covid-19 antara lain gejala gangguan pernapasan akut seperti demam, batuk dan sesak napas. Masa inkubasi rata-rata 5-6 hari dengan masa inkubasi terpanjang 14 hari. Pada kasus COVID-19 yang berat dapat menyebabkan pneumonia, sindrom pernapasan akut, gagal ginjal, dan bahkan kematian. Tanda-tanda dan gejala klinis yang dilaporkan pada sebagian besar kasus adalah demam, dengan beberapa kasus mengalami kesulitan bernapas, dan hasil rontgen menunjukkan infiltrat pneumonia luas di kedua paru [1].

Covid-19 saat ini menjadi permasalahan dunia yang serius dengan jumlah kasusnya yang selalu mengalami peningkatan setiap harinya. Menyerang setiap orang tanpa memandang usia maupun jenis kelamin dan sudah dikategorikan sebagai pandemi global [2]. Pedagang maupun pembeli di pasar seafood atau live market di Wuhan, Provinsi Hubei Tiongkok sudah terkonfirmasi $66 \%$ terjangkit virus ini [3]-[5]. Pandemi global Covid-19 pertama kali diumumkan pada 11 Maret 2020 menandakan bahwa virus ini sudah menjangkiti populasi besar di berbagai negara. Pada tanggal 25 Maret 2020 sudah menjangkiti 175 negara dengan angka penularan sebanyak 425.493 kasus [6].

China masih menempati posisi tertinggi, yaitu 81.637 kasus, tetapi kasus kesembuhan di China juga tinggi, yaitu 73.770 kasus sehingga kasus Covid-19 di China sudah terkendali. Pada 2 Maret 2020, dua kasus pertama dikonfirmasi Indonesia. Tiga minggu kemudian menjadi 790 kasus. Terdapat 24 Provinsi yang sudah mengkonfirmasi ada yang positif virus corona 2019, yaitu Bali, Banten, Yogyakarta, Jakarta, Jambi, Jawa Barat, Jawa Tengah, Jawa Timur, Kalimantan Barat, Kalimantan Timur, Kalimantan
Tengah, Kalimantan Selatan, Kep. Riau, Nusa Tenggara Barat, Sumatera Selatan, Sumatera Utara, Sulawesi Utara, Sulawesi Tenggara, Sulawesi Selatan, Lampung, Riau, Maluku Utara, Maluku dan Papua [7].

Penularan melalui kontak dekat dan droplet, bukan melalui transmisi udara. Orang yang berisiko terinfeksi adalah yang berhubungan dekat dengan orang yang positif covid-19. Tindakan pencegahan merupakan kunci penerapan di pelayanan kesehatan dan masyarakat. Langkah pencegahan di masyarakat adalah dengan menjaga kebersihan tangan menggunakan hand sanitizer jika tangan tidak terlihat kotor. Cuci tangan dengan sabun jika tangan terlihat kotor.

Menghindari menyentuh mata, hidung dan mulut. Dan menerapkan etika batuk atau bersin dengan menutup hidung dan mulut dengan lengan atas bagian dalam. Memakai masker dan menjaga jarak (minimal 1 meter) dari orang lain. Melakukan komunikasi risiko penyakit dan pemberdayaan masyarakat untuk meningkatkan pengetahuan [1]. Penyakit komorbid hipertensi dan diabetes melitus, jenis kelamin laki-laki, dan perokok aktif merupakan faktor risiko dari penyakit Covid-19 [8]-[9]. Tujuan penelitian adalah untuk mengetahui hubungan antara karakteristik individu (umur, jenis kelamin, pendidikan, status pekerjaan, dan posisi dalam keluarga) dengan pengetahuan masyarakat di Kalimantan Selatan tentang pencegahan Covid-19.

\section{Metode}

Penelitian observasional analitik dengan pendekatan cross sectional. Sampel pada penelitian ini berjumlah 1.190 responden di Kalimantan Selatan yang dipilih dengan menggunakan purposive sampling. Pengumpulan data dengan menggunakan kuesioner yang dibantu dengan program google form. Analisa data dilakukan secara univariat dan bivariat (uji chisquare). Penelitian ini dilakukan pada tanggal 13-20 April 2020 dan sebelum dilakukan penelitian sudah mendapatkan ethical clearance dari Komisi Etik Penelitian Kesehatan Fakultas Kedokteran Universitas Lambung Mangkurat Banjarmasin.

\section{Hasil}

Mayoritas yang menjadi responden pada penelitian ini adalah umur remaja $(93,7 \%)$, berjenis kelamin perempuan $(66,3 \%)$, pendidikan tinggi $(93,7 \%)$, tidak bekerja $(77,2 \%)$, status sebagai anggota keluarga di rumah $(97,8 \%)$ dan memiliki pengetahuan yang baik $(69,2 \%)$ (Tabel 1$)$. 
Tabel 1. Distribusi Frekuensi Karakteristik Individu

\begin{tabular}{lrc}
\hline Variabel & Frekuensi & $\begin{array}{r}\text { Persentase } \\
(\%)\end{array}$ \\
\hline Umur & 1.115 & 93,7 \\
Remaja & 48 & 4,0 \\
Dewasa & 27 & 2,3 \\
Lansia & & \\
\hline Jenis kelamin & 401 & 33,7 \\
$\quad$ Laki-laki & 789 & 66,3 \\
$\quad$ Perempuan & & \\
\hline Pendidikan & 71 & 6,3 \\
$\quad$ Pendidikan rendah & 1.115 & 93,7 \\
$\quad$ Pendidikan tinggi & & \\
\hline Status Pekerjaan & 919 & 77,2 \\
$\quad$ Tidak bekerja & 271 & 22,8 \\
$\quad$ Bekerja & & \\
\hline Posisi dalam Keluarga & 26 & 2,2 \\
$\quad$ Kepala rumah tangga & 1.164 & 97,8 \\
$\quad$ Anggota rumah tangga & & \\
\hline Pengetahuan & 366 & 30,8 \\
$\quad$ Kurang baik & 824 & 69,2 \\
$\quad$ Baik & &
\end{tabular}

Responden yang memiliki umur dengan kategori dewasa dan memiliki pengetahuan baik sebanyak $77,1 \%$, kategori remaja dan memiliki pengetahuan yang baik sebanyak $69,1 \%$, sedangkan kategori lansia dan memiliki pengetahuan yang baik sebanyak 63\%. Tidak ada hubungan antara umur dengan pengetahuan tentang pencegahan Covid-19 dengan $p=0,386>0,05$ (Tabel 2).

Responden dengan jenis kelamin perempuan lebih banyak memiliki pengetahuan yang baik $(71,6 \%)$ dibandingkan dengan jenis kelamin laki-laki yang memiliki pengetahuan yang baik $(64,6 \%)$. Ada hubungan antara umur dengan pengetahuan tentang pencegahan Covid-19 dengan $p=0,013<0,05$. Pendidikan yang rendah memiliki pengetahuan yang baik sebanyak $73,3 \%$, sedangkan pendidikan yang tinggi memiliki pengetahuan baik sebanyak $69 \%$. Tidak ada hubungan antara pendidikan dengan pengetahuan tentang pencegahan Covid-19 dengan $p=$ 0,428 > 0,05 (Tabel 2).

Responden yang bekerja memiliki pengetahuan yang baik sebanyak $70,8 \%$, sedangkan responden yang tidak bekerja memiliki pengetahuan baik sebanyak $68,8 \%$. Tidak ada hubungan antara status pekerjaan dengan pengetahuan tentang pencegahan Covid-19 dengan $p=0,428>0,05$. Responden yang menjadi kepala rumah tangga memiliki pengetahuan baik sebanyak $69,2 \%$, sedangkan yang menjadi anggota rumah tangga memiliki pengetahuan baik sebanyak $69,2 \%$. Tidak ada hubungan antara posisi dalam keluarga dengan pengetahuan tentang pencegahan Covid-19 dengan $p=0,999>0,05$ (Tabel 2).

Tabel 2. Hubungan Umur, Jenis Kelamin, Pendidikan, Status Pekerjaan dan Posisi dalam Keluarga dengan Pengetahuan tentang Pencegahan Covid-19

\begin{tabular}{|c|c|c|c|c|c|c|c|}
\hline \multirow{3}{*}{ Variabel } & \multicolumn{4}{|c|}{ Pengetahuan } & \multirow{2}{*}{\multicolumn{2}{|c|}{ Total }} & \multirow{3}{*}{$p$} \\
\hline & \multicolumn{2}{|c|}{ Kurang Baik } & \multicolumn{2}{|c|}{ Baik } & & & \\
\hline & $\mathbf{n}$ & $\%$ & $\mathrm{n}$ & $\%$ & $\mathbf{n}$ & $\%$ & \\
\hline \multicolumn{8}{|l|}{ Umur } \\
\hline Remaja & 345 & 30,9 & 770 & 69,1 & 1.115 & 100 & \multirow{3}{*}{0,386} \\
\hline Dewasa & 11 & 22,9 & 37 & 77,1 & 48 & 100 & \\
\hline Lansia & 10 & 37,0 & 17 & 63,0 & 27 & 100 & \\
\hline \multicolumn{8}{|l|}{ Jenis Kelamin } \\
\hline Laki-laki & 142 & 35,4 & 259 & 64,6 & 401 & 100 & \multirow{2}{*}{0,013} \\
\hline Perempuan & 224 & 28,4 & 565 & 71,6 & 789 & 100 & \\
\hline \multicolumn{8}{|l|}{ Pendidikan } \\
\hline Rendah & 20 & 26,7 & 55 & 73,3 & 75 & 100 & \multirow{2}{*}{0,428} \\
\hline Tinggi & 346 & 31,0 & 769 & 69,0 & 1.115 & 100 & \\
\hline \multicolumn{8}{|l|}{ Status Pekerjaan } \\
\hline Tidak Bekerja & 287 & 31,2 & 632 & 68,8 & 919 & 100 & \multirow{2}{*}{0,515} \\
\hline Bekerja & 79 & 29,2 & 192 & 70,8 & 271 & 100 & \\
\hline \multicolumn{8}{|l|}{ Posisi dalam Keluarga } \\
\hline Kepala Rumah Tangga & 8 & 30,8 & 18 & 69,2 & 26 & 100 & \multirow{2}{*}{0,999} \\
\hline Anggota Rumah Tangga & 358 & 30,8 & 806 & 69,2 & 1.164 & 100 & \\
\hline
\end{tabular}




\section{Pembahasan}

Penelitian ini menunjukkan bahwa tidak ada hubungan yang signifikan antara umur dengan pengetahuan masyarakat di Kalimantan Selatan mengenai pencegahan Covid-19. Rentang umur 36-45 merupakan usia matang dengan pertimbangan seseorang pada umur tersebut akan memiliki pola tangkap dan daya pikir yang baik sehingga pengetahuan yang dimilikinya juga akan semakin membaik. Akan tetapi, ada 6 faktor fisik yang dapat menghambat proses belajar pada orang dewasa diantaranya gangguan penglihatan dan pendengaran sehingga membuat penurunan pada suatu waktu dalam kekuatan berfikir dan bekerja [12].

Faktor lain yang juga menghambat adalah kondisi fisiologis dan psikologi seseorang seperti kondisi seseorang ketika sakit atau ada keterbatasan dalam indra. Tidak adanya hubungan antara umur dengan pengetahuan masyarakat tentang pencegahan Covid-19 di Kalimantan Selatan dapat dikarenakan adanya proporsi yang hampir sama antara kelompok umur remaja, dewasa dan lansia dengan pengetahuan kurang baik. Umur bukan menjadi faktor penghambat sumber informasi masyarakat di Kalimantan Selatan untuk mendapatkan pengetahuan mengenai pencegahan Covid-19, karena masyarakat dengan kategori umur yang berbeda tersebut memungkinkan untuk memiliki keaktifan dan keterpaparan informasi yang sama [13]

Selain itu, pada variabel lainnya ditemukan bahwa ada hubungan yang signifikan antara jenis kelamin dengan pengetahuan masyarakat di Kalimantan Selatan mengenai pencegahan Covid-19. Berdasarkan hasil penelitian, dapat disimpulkan bahwa masyarakat dengan jenis kelamin perempuan cenderung memiliki pengetahuan yang lebih baik tentang pencegahan Covid-19 jika dibandingkan dengan laki-laki. Hal ini disebabkan karena masyarakat dengan jenis kelamin perempuan memiliki lebih banyak waktu untuk membaca atau berdiskusi dengan lingkungannya terkait pencegahan Covid-19.

Rendahnya pengetahuan masyarakat dengan jenis kelamin laki-laki tentang pencegahan Covid-19 akan mendukung meningkatkan angka kejadian Covid19. Hal ini sejalan dengan jumlah kasus Covid-19 bahwa $60 \%$ pasien yang terpapar Covid-19 berjenis kelamin laki-laki. Data ini menunjukan bahwa laki-laki lebih rentan tertular Covid-19. Jumlah kasus positif secara keseluruhan sampai dengan tanggal tersebut adalah sebanyak 13.112 kasus.

Penelitian ini menunjukkan bahwa tidak ada hubungan yang signifikan antara pendidikan dengan pengetahuan masyarakat di Kalimantan Selatan mengenai pencegahan Covid-19. Hal ini disebabkan karena pengetahuan yang didapatkan oleh masyarakat dengan pendidikan rendah mengenai penularan Covid19 tidak hanya dari pendidikan formal tetapi dari pengalaman dirinya maupun lingkungan kehidupan bermasyarakat [14]. Selain itu, pada penelitian ini menunjukkan bahwa tidak ada hubungan yang signifikan antara status pekerjaan dengan pengetahuan masyarakat di Kalimantan Selatan mengenai pencegahan Covid-19. Tidak adanya hubungan antara pekerjaan dengan pengetahuan masyarakat di Kalimantan Selatan tentang pencegahan Covid-19 disebabkan karena antara responden yang bekerja dan tidak bekerja dengan pengetahuan rendah tentang pencegahan Covid-19 jumlahnya hampir sama.

Penelitian ini menunjukkan bahwa tidak ada hubungan yang signifikan antara posisi dalam keluarga dengan pengetahuan masyarakat di Kalimantan Selatan mengenai pencegahan Covid-19. Tidak adanya hubungan antara kepala rumah tangga dengan anggota rumah tangga pada masyarakat di Kalimantan Selatan dengan pengetahuan tentang pencegahan Covid-19 dapat disebabkan karena adanya proporsi yang sama antara kedua kategori responden tersebut, yaitu masing-masing sebesar 69,2\%. Penyakit ini harus diwaspadai karena penularan yang relatif cepat, memiliki tingkat mortalitas yang tidak dapat diabaikan, dan belum adanya terapi definitif. Masih banyak kesenjangan pengetahuan yang terjadi terkait penyakit ini berdasarkan karakteristik individu yang telah diteliti, sehingga diperlukan upaya penanggulangan dan studi-studi lebih lanjut [15].

\section{Kesimpulan}

Jenis kelamin memiliki hubungan yang signifikan dengan pengetahuan tentang pencegahan Covid-19. Sedangkan umur, pendidikan, status pekerjaan dan posisi dalam keluarga tidak memiliki hubungan dengan pengetahuan tentang pencegahan Covid-19. Perlu dilakukan penelitan selanjutnya mengenai intervensi berbagai media pendidikan kesehatan untuk meningkatkan pengetahuan masyarakat tentang pencegahan Covid-19.

\section{Ucapan Terima Kasih}

Terima kasih kepada masyarakat Kalimantan Selatan yang sudah menyempatkan waktunya untuk berpartisipasi dalam penelitian ini di masa pandemi pada saat dilakukan penelitian ini.

\section{Daftar Pustaka}

[1] Direktorat Jenderal Pencegahan dan Pengendalian Penyakit (P2P). Pedoman Pencegahan dan Pengendalian Coronavirus Disesase (Covid-19). Jakarta: Kementerian Kesehatan RI. 2020.

[2] World Health Organization. 2020. Novel Coronavirus.

[3] Huang, C. Wang, Y. Li, X. , Renc, L. Zhao, J. Zan, G.Li., Fan, G., Etc. 2020. Clinical Features Of Patient Infectted With 2019 Novel Coronavirus In Wuhan, China. The Lancet.

[4] Wuhan Municipal Health Commission. Report Of Clustering Pneumoniaof Unknown Etiology In Wuhan City. 2019.Http://Wjw.Wuhan. 
Gov.Cn/Front/Web/Showd

123108989. Accessed December 31, 2019

[5] Feng He, Yu Deng, Weina Li. Coronavirus. Disease 2019: What We Know?. J Med Virol. 2020.1-7.

[6] John Hopkins University \& Meidicine Coronavirus Resource Center, Https://Coronavirus.Jhu.Edu/Map.Html , Pada 25 Maret 2020 Pukul 16.39 WIB.

[7] Tahrus ZNH. Dunia Dalam Ancaman Pandemi: Kajian Transisi Kesehatan dan Mortalitas Akibat Covid-19. Kajian Demografi Sosial Departemen Sosiologi, FISIP UI. 2020.

[8] Fang L, Karakiulakis G, Roth M. Are Patients With Hypertension And Diabetes Mellitus At Increased Risk For COVID-19 Infection? Lancet Respir Med. 2020; Published Online March 11. DOI: 10.1016/S22132600(20)30116-8.

[9] Cai H. Sex Difference And Smoking Predisposition In Patients With COVID-19. Lancet Respir Med. 2020; Published Online March 11. DOI: 10.1016/S22132600(20)30117-X 42.

[10] Departemen Kesehatan RI. 2009. Klasifikasi Umur Menurut Kategori. Jakarta: Ditjen Yankes.
[11] Fauzie Rahman, et al. Evaluation Of The Association Between Hypertension And The Factors: Gender, Age, Education Level And Work Status In Pantai Linuh, Indonesia. Southeast Asian J Trop Med Public Health 2018; 49(6):1072-1077.

[12] Maulana, H. Promosi Kesehatan. Jakarta: Penerbit Buku Kedokteran EGC. 2007.

[13] Nurmala, I., Rahman, F., Nugroho, A., Erlyani, N., Anhar, VY. Promosi Kesehatan. Surabaya: Airlangga University Press. 2018

[14] Muslima, T.K., Ernawaty, J., Woferst, R. 2012. Faktor-Faktor Yang Mempengaruhi Tingkat Pengetahuan Orang Tua Terhadap Dampak Televisi Pada Perkembangan Anak Usia Sekolah. Artikel Penelitian. Universitas Riau. 2012.

[15] Susilo A, C. Martin Rumende, Ceva W Pitoyo, Widayat Djoko Santoso, Mira Yulianti, Herikurniawan, Robert Sinto, Gurmeet Singh, Leonard Nainggolan, Erni J Nelwan, Lie Khie Chen, Alvina Widhani, Edwin Wijaya, Bramantya Wicaksana, Maradewi Maksum, Firda Annisa, Chyntia OM Jasirwan, Evy Yunihastuti. Coronavirus Disease 2019. Jurnal Penyakit Dalam Indonesia 2020; 7(1): 45-67. 